\title{
Comparing RUSLE to WEPP Cropland and Rangeland Formats
}

\author{
W. J. Elliot ${ }^{1}$
}

\begin{abstract}
Rangeland runoff and erosion rates are highly dependent on the type and amount of vegetative cover as well as climate and topography. Three rangeland erosion prediction models, RUSLE, WEPP for rangelands, and FS WEPP for rangelands were compared to observed sedimentation rates on five small southeastern Colorado watersheds. RUSLE and the FS WEPP interface gave predictions similar to the observed values for sedimentation. The WEPP rangeland templates underpredicted erosion and overpredicted runoff. Both versions of WEPP were able to predict runoff as a function of upland topography and vegetation, making future development of more complex rangeland watershed sedimentation prediction feasible.
\end{abstract}

Keywords. Erosion models, Modeling, Rangeland, RUSLE, WEPP.

\section{Introduction}

Rangelands, like all land surfaces, are susceptible to soil erosion by water. Soil erosion can reduce upland productivity, and adversely impact aquatic ecosystems and other beneficial uses of surface water. Erosion can occur on upland areas or in channels. The dominant erosion processes in the uplands are interrill (raindrop splash and shallow overland flow), and rill (concentrated overland flow) erosion. In channels, gully processes (headcutting), channel scour, and bank erosion are common. In some conditions, depositional processes in the stream or flood plains may dominate the sedimentation processes. On rangeland, the dominant processes tend to be either rill and interrill on upland sites, and gully and stream erosion during major runoff events.

\section{Role of Management}

Vegetation plays a complex and important role in rangeland erosion processes. The amount of vegetation is highly dependent on the seasonal rainfall for within-year growth, and long term climate and management patterns for the mix of plant species. Vegetation reduces soil water content through evapotranspiration, which is dependent on the availability of soil water and depth of rooting, the climate, and the plant species. Vegetation also produces surface residue.

Grazing reduces the amount of vegetation available to become soil cover. It can also compact the soil, decreasing soil water holding capacity and decreasing infiltration rates, leading to increased runoff. Compacted soil may be less erodible, but the increased runoff will likely lead to a greater net erosion rate. Also, grazing causes cattle paths with no vegetation, which can concentrate runoff and initiate the gully formation process.

\section{Soil Properties}

Rangeland soils tend to have low erodibilities. They are not disturbed by tillage, as common with agricultural soils. They frequently have a surface with a significant stone cover which is likely due to armoring from many years of water and wind erosion.

The hydraulic conductivity of a rangeland soil appears to vary with the type of vegetation (Flanagan and Livingston, 1999; Franks et al., 1998). Soils beneath shrub or juniper coppice communities tend to have the highest conductivities, with grass soils somewhat lower, depending on cover and condition. Conductivities, however, vary widely with texture and cover. Figure 1 shows the distribution of hydraulic conductivities from a recent study for different soil textures, cover, and plant communities.

\section{Current Prediction Models}

RUSLE has been developed for both agricultural and range lands (Renard et al., 1997). It models upland erosion processes only, and has no stream channel prediction capabilities.

${ }^{1}$ Corresponding author: Project Leader, USDA Forest Service, Rocky Mountain Research Station, 1221 South Main, Moscow, ID; tel.: (208) 883-2338; fax: (208) 883-2318; e-mail: <welliot@fs.fed.us>. 
The Water Erosion Prediction Project (WEPP) model is a physicallybased model that describes the processes that cause erosion (Flanagan and Livingston, 1995). The vegetation can be described in a rangeland or a cropland format. The WEPP Rangeland model describes plant growth as a single or double-peak function, and allows removal of vegetation by grazing. In the cropland format of WEPP model, plant growth rate depends on the biomass conversion ratio value input to WEPP for a given plant, solar energy, temperature, and the availability of soil water.

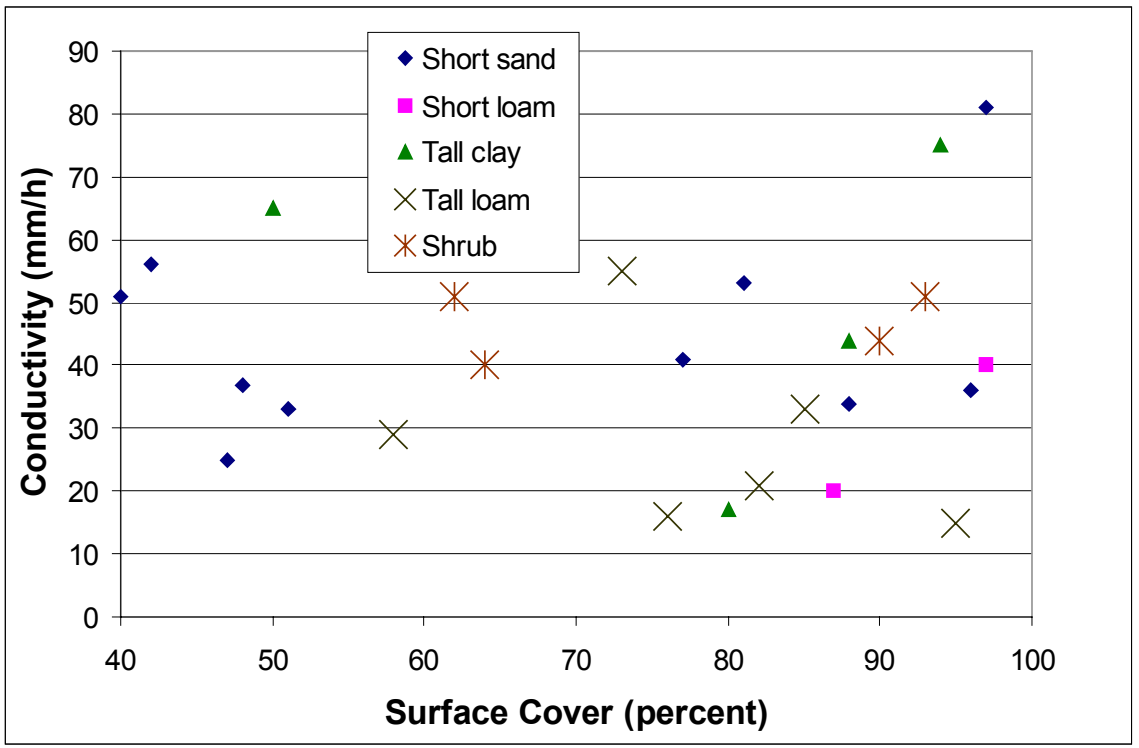

Figure 1. Observed hydraulic conductivity values for a number of different soil textures, vegetation (short grass, tall grass, and shrubs) and surface cover amounts (from Franks et al., 1998).

To capture the ability

of WEPP to model site-specific erosion, while keeping the interface simple, we have developed a web browser interface. The interface (FS WEPP) predicts average annual runoff erosion, and sediment yield values, and also determines annual probabilities of runoff and erosion. FS WEPP uses the cropland format to describe all vegetation scenarios, and its soil database varies soil properties with texture and with type of vegetation (Elliot et al., 2000)

\section{Model Comparison}

The U.S. Geologic Survey carried out a water quality study on a $990 \mathrm{~km}^{2}$ rangeland military site in southeastern Colorado (von Guerard et al. 1987). The site ranged in elevation from 1326 to $1800 \mathrm{~m}$. The annual precipitation is about $300 \mathrm{~mm}$, and the soils range from fine to coarse, depending on the parent material. During the last 100 years, the area has been used for livestock grazing and later, military maneuvers. The purpose of the USGS study was to evaluate the impact of military activities on surface and ground water quality.

As part of that study, the USGS measured the sediment that had accumulated in 48 stock watering ponds on 29 watersheds ranging from 20 to 416 ha. The mean annual sediment yields from these watersheds ranged from $0.03 \mathrm{t} \mathrm{ha}^{-1}$ to $5.97 \mathrm{t} \mathrm{ha}^{-1}$.

Five watersheds were selected from the study area for model comparison. Preference was given to the smaller watersheds where upland erosion rather than channel erosion processes would dominate, since both the current WEPP versions and RUSLE are intended to model upland erosion only. The properties of the watersheds are summarized in Table 1.

Table 1. Properties of model validation watersheds

\begin{tabular}{|c|c|c|c|c|c|c|}
\hline No & $\begin{array}{c}\text { Area } \\
\text { ha }\end{array}$ & $\begin{array}{c}\text { Sed Yield } \\
\text { t/ha }\end{array}$ & Soil & $\begin{array}{c}\text { Topograp } \\
\% \text { slope }\end{array}$ & $\begin{array}{c}\text { Slope L } \\
\mathrm{m}\end{array}$ & $\begin{array}{c}\text { Cover } \\
\% \\
\end{array}$ \\
\hline 1 & 39 & 0.13 & loam & 2.5 & 330 & 50 \\
\hline 7 & 26 & 5.97 & clay & 25 & 300 & 35 \\
\hline 27 & 29 & 2.57 & sand & 25 & 250 & 30 \\
\hline 38 & 26 & 0.98 & loam & 2.5 & 250 & 25 \\
\hline 45 & 34 & 2.75 & loam & 22 & 300 & 35 \\
\hline avg & 30.6 & 2.48 & & 15.4 & 286 & 35 \\
\hline
\end{tabular}


Table 2. Assumptions for RUSLE and the WEPP models

\begin{tabular}{|c|c|c|c|}
\hline Watershed & RUSLE & $\begin{array}{l}\text { WEPP Windows for } \\
\text { Rangelands }\end{array}$ & $\begin{array}{l}\text { FS WEPP } \\
\text { Rangeland Vegetation }\end{array}$ \\
\hline \multicolumn{4}{|c|}{ Climate } \\
\hline All & $\begin{array}{l}\text { Pueblo, CO } \\
\mathrm{R}=40\end{array}$ & \multicolumn{2}{|c|}{ Timpas, CO, Annual Precipitation $=413 \mathrm{~mm}$} \\
\hline \multicolumn{4}{|c|}{$\underline{\text { Soils }}$} \\
\hline \multirow[t]{2}{*}{1} & \multirow[t]{2}{*}{$\mathrm{K}=0.25$} & $\mathrm{Kr}=0.0 \overline{085}$ & $\mathrm{Kr}=0.0003$ \\
\hline & & $\mathrm{Ksat}=6 \mathrm{~mm} \mathrm{~h}^{-1}$ & $\mathrm{Ksat}=30 \mathrm{~mm} \mathrm{~h}^{-1}$ \\
\hline \multirow[t]{2}{*}{7} & \multirow[t]{2}{*}{$\mathrm{K}=0.28$} & $\mathrm{Kr}=0.0085$ & $\mathrm{Kr}=0.0002$ \\
\hline & & Ksat $=5 \mathrm{~mm} \mathrm{~h}^{-1}$ & Ksat $=18 \mathrm{~mm} \mathrm{~h}^{-1}$ \\
\hline \multirow[t]{2}{*}{27} & \multirow[t]{2}{*}{$\mathrm{K}=0.20$} & $\mathrm{Kr}=0.0085$ & $\mathrm{Kr}=0.0005$ \\
\hline & & $\mathrm{Ksat}=8 \mathrm{~mm} \mathrm{~h}^{-1}$ & $\mathrm{Ksat}=25 \mathrm{~mm} \mathrm{~h}^{-1}$ \\
\hline \multirow[t]{2}{*}{38,45} & \multirow[t]{2}{*}{$\mathrm{K}=0.25$} & $\mathrm{Kr}=0.0085$ & $\mathrm{Kr}=0.0003$ \\
\hline & & $\begin{array}{r}\text { Ksat }=6 \mathrm{~mm} \mathrm{~h}^{-1} \\
\text { Vegetation }\end{array}$ & $\mathrm{Ksat}=23 \mathrm{~mm} \mathrm{~h}^{-1}$ \\
\hline 1 & $\mathrm{C}=0.0248$ & Northern mixed prairie & Tall grass, Cover $=50 \%$ \\
\hline 7 & $\mathrm{C}=0.0257$ & Northern short prairie & Short grass, Cover $=35 \%$ \\
\hline 27 & $\mathrm{C}=0.0445$ & Northern short prairie & Short grass, Cover $=30 \%$ \\
\hline 38 & $\mathrm{C}=0.0985$ & Northern short prairie & Short grass, Cover $=25 \%$ \\
\hline 45 & $\mathrm{C}=0.0257$ & Northern short prairie & Short grass, Cover $=35 \%$ \\
\hline
\end{tabular}

\section{Validation Procedure}

Certain assumptions were required for validation (table 2). The climate for the two WEPP interfaces, Timpas, CO, was located at the edge of the study site. The nearest RUSLE climate was Pueblo, CO. The RUSLE $C$ factors were calculated from the cover (table 1) and the rangeland plant communities (table 2). Values from table 2 were entered into the respective models for each watershed, and the results noted. Overall means, and the error sum of squares were calculated for each model. Runoff amounts had been estimated for two years from three of the selected watersheds. Both versions of the WEPP model predicted runoff for their runs for an average of thirty years.

\section{Results and Discussion}

The sediment delivery results are presented in table 3, and the runoff comparisons in table 4. From table 3 , the FS WEPP model and RUSLE appear to be better predictors of soil erosion than the WEPP rangeland model.

RUSLE is intended to predict upland erosion, and not sediment delivery, so the predicted values may likely be greater than the observed values. The $L S$ factor, which was developed from agricultural research, may be over-compensating for the higher values.

The rangeland templates from the WEPP model appear to under predict sedimentation (table 3) while over predicting the runoff amounts (table 4). As the observed runoff values were for only two years, it is possible that those years may have been drier than the average annual precipitation for the Timpas, CO climate (413 $\mathrm{mm}$ ). Von Guerard et al. (1987) had stated that the average precipitation was around $300 \mathrm{~mm}$.

The FS WEPP predictions result in the lowest error in sediment delivered, and they are the closest of the two WEPP versions in predicting runoff. There is a small over prediction of erosion, which may be due to the channel processes that were not modeled, and an over prediction in runoff, which may be due to differences

Table 3. Results from erosion models, sediment yield in $\mathbf{t h a}^{-1}$

\begin{tabular}{ccccc}
\hline Watershed & Observed & RUSLE & WEPP rangeland & FS WEPP \\
\hline 1 & 0.13 & 0.20 & 0 & 0.05 \\
7 & 5.97 & 6.52 & 1.08 & 5.34 \\
27 & 2.57 & 7.64 & 0.50 & 4.79 \\
38 & 0.98 & 0.92 & 0 & 0.63 \\
45 & 2.75 & 4.94 & 0.50 & 4.49 \\
\hline Mean & 2.48 & 4.04 & 0.42 & 3.06 \\
Error SS & & 30.87 & 34.2 & 8.5 \\
\hline
\end{tabular}


between the average climate which ran the model compared to the weather the two years that runoff was observed.

Not knowing the exact weather that caused the observed runoff makes detailed comparisons of runoff inappropriate. With both versions of WEPP, the runoff amount was a function of both topography and vegetative cover.

This feature will make future development of the model for rangeland runoff, erosion, and channel processes as impacted by upland vegetation feasible.

\section{Impact of Vegetation on Runoff}

From the modeling results, it appears that both versions of WEPP are able to model the differences of vegetation on runoff. A sensitivity analysis was carried out to quantify this relationship with FS WEPP. A typical hillslope with a loam soil, $200 \mathrm{~m}$ long, with a 20 percent slope (decreasing to 8 percent at the base) was entered along with the Timpas, CO climate. The vegetation was set to provide 30 , 50, and 80 percent cover for both good and poor grass soil properties. The results of these six runs are presented in figure 2 . At low levels of cover, the effect of the cover on the soil results in large differences in erosion as well as runoff. At higher levels of cover, both erosion and runoff decline to the point that there is little difference between the two plant communities. Apparently, the effects of greater amounts of cover tend to overshadow soil differences in the WEPP cropland version.
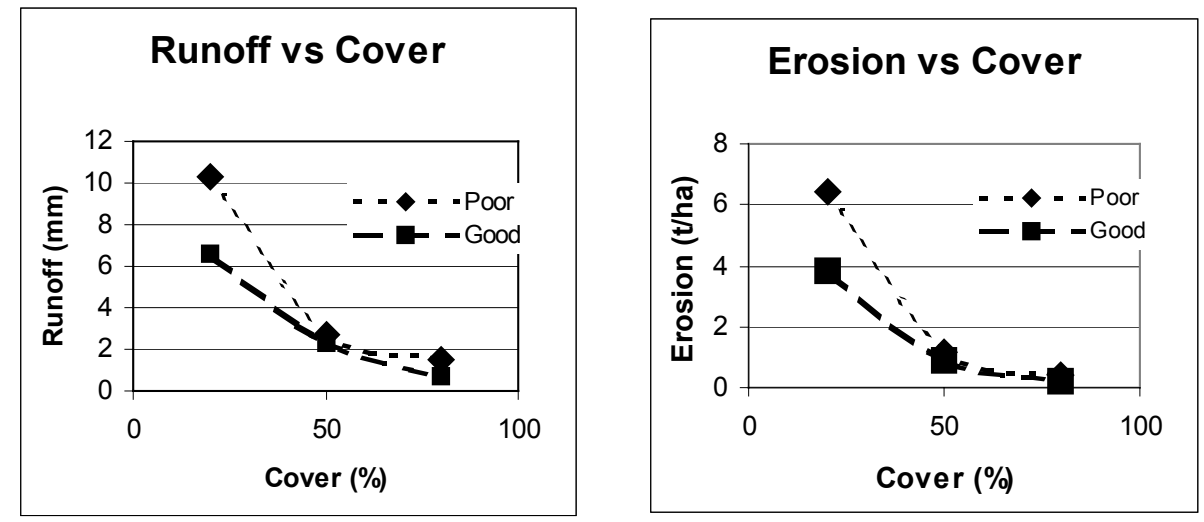

Figure 2. Impact of cover and vegetation type on predicted runoff and soil erosion.

\section{References}

Elliot, W. J., D. E. Hall, and D. L Scheele. Forest Service Interfaces for the Water Erosion Prediction Project Computer Model [Online]. Available: http://forest.moscowfsl.wsu.edu/fswepp/ [Feb 10, 2000].

Flanagan, D. C., and S. J. Livingston. 1995. WEPP User Summary. NSERL Report No. 11, W. Lafayette, IN: National Soil Erosion Research Laboratory. $131 \mathrm{pp}$.

Franks, C. D., F. B. Pierson, A. G. Mendenhall, K. E. Spaeth, and M. A. Weltz. 1998. Interagency Rangeland WaterErosion Project Report and State Data Summaries. Interagency rangeland water erosion team (IRWET) and National Range Study Team (NRST). NWRC 98-1. Boise, ID: USDA ARS Northwest Watershed Research Center. $121 \mathrm{pp}$.

Renard, K. G., G. R. Foster, G. A. Weesies, D. K. McCool, and D. C. Yoder, coordinators. 1997. Predicting soil erosion by water: A Guide to Conservation Planning With the Revised Universal Soil Loss Equation (RUSLE). Agriculture Handbook No. 703. Washington D.C.: U.S. Department of Agriculture. 404 pp.

von Guerard, P., P. O. Abbott, and R. C. Nickless. 1987. Hydrology of the U.S. Army Pinon Canyon Maneuver Site, Las Animas County, Colorado. Water-Resources Report 87-4227. Denver CO: U.S. Department of Interior Bureau of Land Mangement. $113 \mathrm{pp.}$ 